\title{
Correction to: Litterfall seasonal dynamics and leaf-litter turnover in cocoa agroforests established on past forest lands or savannah
}

\author{
Stephane Saj • Annemarijn Nijmeijer • Jean-Daniel Essobo Nieboukaho • \\ Pierre-Eric Lauri $\cdot$ Jean-Michel Harmand
}

Published online: 3 April 2021

(C) The Author(s), under exclusive licence to Springer Nature B.V. part of Springer Nature 2021

\section{Correction to: Agroforest Syst https://doi.org/10.1007/s10457-021-00602-0}

In the original publication of the article the affiliation for the author "Pierre-Eric Lauri" was incorrectly published. This has now been corrected with this Correction. The original article has been corrected.

Publisher's Note Springer Nature remains neutral with regard to jurisdictional claims in published maps and institutional affiliations.

The original article can be found online at https:// doi.org/10.1007/s10457-021-00602-0.

S. Saj $(\varangle) \cdot$ A. Nijmeijer · P.-E. Lauri ABSys, Univ Montpellier, CIRAD, CIHEAM-IAMM, INRAE, Institut Agro, Montpellier, France e-mail: stephane.saj@cirad.fr

S. Saj · A. Nijmeijer

UMR ABSys, CIRAD, 97310 Kourou, France

A. Nijmeijer · J.-D. E. Nieboukaho

Département des plantes stimulantes, IRAD, Yaoundé, Cameroon

J.-M. Harmand

INRAE, IRD, Eco\&Sols, Univ Montpellier, CIRAD,

Institut Agro, Montpellier, France

J.-M. Harmand

UMR Eco\&Sols, CIRAD, Montpellier, France

J.-M. Harmand

World Agroforesty (ICRAF), Yaoundé, Cameroon 